\title{
Applied Research in the Production of a Genre Film: Production Design and Realization of a School Movie
}

\section{Nikolaos Aletras}

School of Film, Faculty of Fine Arts, Aristotle University of Thessaloniki

\section{Abstract}

The production of a film for research purposes (film-based research) is a growing qualitative scientific research method, applied in many scientific fields. The researcher of the film-based research is an active part of the process, aiming at formulating questions and disputes rather than seeking answers. The object of the research is located in the cinematic production of a fiction film belonging to the genre of School Movies, in combination with the application of the auteur theory. The results of the present study highlight the importance of the personality of the researcher, who should balance between scientific principles and the needs and requirements of film production.

Keywords: film-based research, School Movies, auteur theory, film production

\section{Introduction}

This article describes the results of my postdoctoral research entitled "Applied research in the production of a genre film: production design and realization of a School Movie". This research has been conducted at the School of Film of the Aristotle University of Thessaloniki for two years, from 20/11/2018 to 20/11/2020. The investigation emerged as a result of my involvement with my doctoral dissertation on the genre of School Movies. More specifically, it is motivated by the study of the formation and evolution of School Movies, a category of films that presents specific semantic, syntactic and pragmatic features (according to Altman's approach), and utilizing the auteur theory, I searched - in an applied research level - those elements that lead to the production of a School Movie. During the first months of the second year of research, the restrictions imposed due to the pandemic of coronavirus, and the subsequent objective difficulties, led to a redefinition of research objectives with an emphasis on organizing and planning Do It Yourself production model, excluding the production elements and post-production process. 


\section{Literature review}

The arts based research is a new phenomenon which uses the arts (music, poetry, literature, dance, theater, cinema) as research approaches to capture qualities of life that have an impact on what we know and what we live (Barone, 2003). Such contributions can be found in the poetic use of language, in the expressive use of narrative, and in the sensory creation of a cinematic film. In recent years, the use of arts based research finds several applications in many scientific fields. In the case of Barone (2003), the arts based research uses the artistic expression, as a way to present a set of images from the existing educational process, which will lead to an understanding of teachers' and students' educational experience. Images of school life, basically negative in public schools for an outside observer, come to light with the help of a film or documentary.

In his article Challenging the Educational Imaginary: Issues of Form, Substance, and Quality in Film - Based Research, Barone (2003) deals with quality issues in film-based educational research projects. He proposes the criteria related to both the aesthetic form and the substance, which are appropriate for assessing the usefulness of educational films, in the effort to achieve a possible goal for educational research based on cinema. The goal of this effort is to effectively address the educational establishment imaginary. This imagery is described as a set of images of schools and school people, rooted in the wider culture which advocates a grueling narrative about education. Issues of quality and usefulness are explored in the context of a film, made by an educator and presented (among other things) at film festivals or at the pedagogical school of the author himself (Barone, 2003).

As a key branch of arts based research, the film-based research is a method which, according to Wood \& Brown (2012), "(its) aim is to construct a framework from which to analyse the interconnection between filmmaking, as a mode of aesthetic engagement, and the system of domination that shapes the parameters of qualitative research. A key insight that emerges from this analysis is that the practice of filmmaking can be a highly affective form of qualitative research in itself, with its own distinctive mode of communicating thoughts and feelings together" (Wood \& Brown, 2012, p. 131) .

An important addition to the theoretical framework of the film-based research is the article by Martin Wood, Perttu Salovaara and Laurent Marti (2003), Manifesto for film making as organisational research, in which the authors make four basic principles on the subject of organizational studies: rescue of the research field, provocation of new thought, design of a non-conventional research and, finally, integrating production and distribution (Wood, Salovaara \& Marti, 2018).

\section{Main objectives and assumptions of research}

Assuming that the production of a cinematic work is a method of scientific research (film-based research) which uses the means and processes of the applied art of 
cinema, I can state the main objective of the research, which is the production of a genre film and specifically, a School Movie.

In this case, the proposed research which can be viewed as an applied analysis of both the film genre of School Movies and the auteur theory reflects on the personality of the scientist - film producer. Therefore, the main objectives of the postdoctoral research were formulated as follows:

The planning, organization and execution of the production of a digital movie that belongs to the genre of School Movies, that is, a film which contains specific semantic / syntactic / pragmatic characteristics, as defined by me in my phd thesis (Aletras, 2018).

The study of the role of a film producer, who is not only treated as the coordinator of the project, but he is in charge of many qualities (screenwriter, director, etc.), too. The researcher-film producer can be treated as an auteur, in the research context set by Brown \& Wood in 2012, and according to the characteristics given to the term by Francois Truffaut. Truffaut's views were transformed into an aesthetic theoretical movement, that of "politique des auteurs", according to which «auteurs are treated as authors or artists whose creative voice has a particular influence on all stages of film production, from planning and directing, up to post-production management. An example of a cinematic auteur is Hitchcock, who is considered - according to Sarris the 'touchstone of touchstones' of the movement "(Wood and Brown, 2012, p. 134).

\section{Research method}

According to what has been presented in the literature review, the methodological core of this proposal is the new form of arts based research and specifically, that based on film-based research. In this sense, the planning of film production of a School Movie (fiction film) in combination with the application of the creator's theory is an innovative application of film-based research that will lead to useful research experiences and conclusions, which will be evaluated both methodologically (what is the value of film-based research as a research method) and in relation to the academic view of the object of film production (similar research was conducted by Brown \& Wood in 2009 shooting the short documentary Lines of Flight). Based on the above, the production of a cinematic piece of work is not only the object of the research but also a strongly emerging method of qualitative research that involves the researcher, as an active part of field research. In this case, the researcher-filmmaker becomes auteur himself, "creating" through the research process and, at the same time, gaining sensory experiences since the film production (both as a practice and as an object of a study) determines behaviors, emotions and identifications that characterize the professional filmmaker.

The film-based research has been expressed mainly by documentary films. Fiction films are the subject of a scientific analysis in a theoretical context rather than the object of cinematic scientific research. That is why the films made in the context of a 
scientific research are documentaries, many of which - in recent years - contain strong elements of drama and fiction. Documentaries become a form of cinema that - most of the time - combine the recording of reality with the personal stamp of their creators.

As an example, Barone (2012) mentions the movie Fear and Learning at Hoover Elementary (Simon, 1997), a documentary, filmed by the teacher Laura Simon, who was a teacher in a primary school in Los Angeles with, mostly, latin-speaking students. The film - as reported by Barone - traces events that arose as a result of the implementation of a legislative regulation according to which, teachers were obliged to report to the authorities the students who were illegal immigrants. The film dramatically captures the effects of the regulation on the lives and relationships of the characters, with the director using documentary techniques and thorough editing of the footage, in order to engage viewers in the difficult situations the characters experience (Barone \& Eisner, 2011, pp. 25-26).

Most films of this kind are a form of qualitative ethnographic research, with their creators not necessarily being related to academic research. Great filmmakers such as Frederick Wiseman and Michael Moore have left their personal mark through documentaries. Wiseman's documentaries are a special case study of state institutions [Titicut Follies (1967), High School (1968), High School II (1994)]. The absence of a narrator, interviews and the fact that the main characters do not look directly at the camera, give an indirect feeling to the viewer (Nichols, 1978). With the new cinematic techniques and the evolution of technology, along with the wave of controversy brought by the new filmmakers (with F. Wiseman being one of them) compared to the old ones, the line between classic films and documentaries had already been blurred since the '60s and '70s (Donato,2007). Wiseman's documentaries are modern ethnographies of organizations, capturing with graphic details, norms, culture, values and systems within the organizations. Wiseman was able to capture the true meaning of an organization through examples, which may seem random to the casual observer. For research purposes, in a business administration training program, Wiseman's projects were used as a reference to introduce students to "organizational reality" (Scherer \& Baker, 1999), with particularly positive results. In the case of Michael Moore, the director himself becomes the protagonist of his research, participating and co-shaping the progress in an activist way (Fahrenheit 9/11, Bowling for Columbine). The result is making films that have dramatic climaxes and script twists, which proves that the boundaries between documentaries and fiction are becoming increasingly blurred.

In the case of Brown \& Wood (2012), the two authors describe their own research effort, using the film- based research method, when in 2009 they shot the film Lines of Flight, which, as they describe, is an application of the auteur theory in film production. Their award-winning work "is both a micro- ethnography of free climbing, a visual geography of the Pennines in North England, an expression of Deleuze's film philosophy and, finally, a socio- historical critique of the oppression and resistance of 
the working class. We use the film to challenge and engage viewers in aesthetic experiences they have not experienced, as if they had actually experienced them. By integrating sounds and images into emotional, dynamic and aesthetic terms, we invite viewers to reflect on their own personalities, emotions and ideas. In addition, as researchers, we extend this ability to reflect ourselves in our own 'implementation practices' of production. By focusing on the specificity of our experiences, we practically contribute to literacy on sensory methodologies" (Wood \& Brown, 2012, pp. 131-132).

Evaluating Brown \& Wood's film, Lines of Flight, it is easy to see that this is an excellent cinematic creation-research, which accurately captures the application of the auteur theory in cinematic production. Furthermore, this research has been the model for me to proceed with my postdoctoral research using, this time, the auteur theory on film production of a School Movie.

\section{Findings}

In accordance with the objectives of research, I attempted to produce a school movie, that is, a film governed by specific ideological semantic / syntactic / pragmatic frameworks. Specifically, based on the findings of my doctoral research Types of Teachers and Educational Systems in cinema. Analysis of the most important School Movies of world film production, the School Movies are a distinct category of fiction films with main characters teachers and students placed inside school and society. The films of the genre are realistic, with the main syntactic mean, the pursuit of education, which is based on the dialectical contradiction between the purpose (education) and the expedient (educational system). The pragmatic framework is defined by the interactions of multiple users, who are influenced by the respective ideological and economic systems of the country of production (Aletras,2018).

The use of Altman's semantic / syntactic / pragmatic approach was the main methodological tool for documenting the genre of School Movies. The application of this method clearly identified types of teachers (punisher, ideal, democratic, supportive, activist, intellectual, cynical, indifferent, bureaucratic, authoritarian), who seek the best education in a social and racial divided environment, which is expressed by the various educational systems. Therefore, School Movies is a separate and autonomous genre of feature-length fiction films, based on the combination of semantic elements (teacher / student within school and society), which acquire a stable syntax, and which is based on the aim for education. School Movies, created their own film curriculum, representing, in cinematic terms, the equivalent actual, while the film production process of School Movies been fixed by the ideological and economic systems in the countries of production. Also, the diachronic and historical evolution of the genre is reflected through the depicted types of teachers and educational systems, while their themes are related to the economic, political, ideological and racial characteristics of societies. Taking these into account, the semantic / syntactic / pragmatic elements of School Movies - based on the characteristics of real life school - compose a filmic self-existent world, which 
contributes to the interaction of the real model with the corresponding cinematic one, having the spectators and multiple users of the genre, as intermediates. These changes - usually invisible - create new situations and express new problems that arise over time.

The theoretical framework of the conclusions of my doctoral dissertation was the basis for my postdoctoral research, the time and planning of which covered a period of two years. The research was originally planned based on usual cinematic production process (pre-production, production, post-production) and, specifically, on features of individual film production, in which "the division of labor is very small: the filmmaker oversees every production work, from funding to final editing, and actually performing many of these tasks himself " (Bordwell \& Thompson, 2011, p. 48). In this way, the digitally produced School Movie will serve the objectives of the research and, at the same time, it will be defined by low cost, not "because of its existence, but as part of its logic" (Dimitriou,2011, p. 146) .

Since most of the research was the result of my own effort, I attempted the stage of pre-production (18 months) to cover the biggest part of the schedule. During that time, a lot of actions took place so that, later, at the stage of production (i.e. shooting), as little time as possible and small number of employees would be required. In the pre-production stage, all those procedures that will create the conditions were defined and planned, so that there is a smooth and short filming as well as the completion of the process. During that time, the script was completed. The title of the screenplay is Kalamonas and is based on the real facts concerning the students' uprising of the 4th Grade of Zosimaia High School in 1900, during the Ottoman rule period, in Ioannina City. The development of the original idea into a screenplay as well as the writing of the text were realized by me, of the final text. In the spring of 2020, due to objective difficulties arising from the measures taken to combat the covid-19 pandemic, the objectives of the research were redefined, with an additional emphasis on the organizing and planning of film production, focusing on its thorough story in storyboard, using special software (iClone, Blender). The storyboard provides «a preliminary picture of what the plans should look like in their final form. Before filming the Godfather III, Francis Ford Coppola filmed it on video with extras' voices narrating the dialogue» (Bordwell \& Thompson, 2011, p. 37). The approach described was followed by many auteurs, in the past and nowadays. The case of Alfred Hitchcock who "planned each shot in advance, and explained to the director of photography, in detail, what he exactly wanted, is such an example» (Bordwell \& Thompson, 2011, p. 59). In this way he managed to have maximum creative control over the artistic result of his vision, and - at the same time - to minimize the cost of production, although he was part of the costly Hollywood film industry. Another typical example is the Estonian school bullying movie, Klass (2007) by Ilmar Raag . In this film, the preproduction stage lasted six months while the shooting lasted just twelve days (Aletras,2018). 


\section{Discussion and Conclusions}

The film production researcher resembles the do it yourself filmmaker, who - due to circumstances and financial difficulties - is forced to reinvent methods and approaches that will help him realize his vision. The scientist / researcher, like the do it yourself filmmaker, takes the conditions and means at his disposal into account, and tries to use them as effectively as possible, in order to solve problems that may arise. The do it yourself researcher / producer reaches his goals through continuous tests, which finally form a path towards self-realization through the continuous analysis of the facts and the (self) critical thinking. The do it yourself model can be a holistically person-centered way of production but it fits in with film-based research, a dynamic research method that places the researcher / producer at the center of the research production process. The researcher - under certain conditions - can become a filmmaker (auteur). That depends on how creative and imaginative he can become, acting himself as an autonomous personality, in a scientific way in the field of real film production. For example, during screenwriting, and trying to apply theory to practice, I experimented with combining elements of film theory (Altman's semantic / syntactic approach) with screenwriting techniques, as described by Syd Field (three act structure, characters, obstacles, plot points, resolution, etc.). In my endeavor, there was always the danger of standardization, which, in fact, undermines artistic inspiration and innovation. Such a danger, however, is faced by the filmmakers themselves, when they make films of this kind. In order to avoid it, they seek to enrich the contracts with new elements of the genre. This is how they manage to evolve the film genres, letting their creative imagination surprise the viewers, even though they use the same "recipe". The final script of Kalamonas makes up a school movie with features of many cinematic genres: action, adventure and suspense, historical drama, story of characters with strong political elements, and western. What I paid special attention to, is to create an ecumenical story with a strong Greek imprint in its narration. However, writing the script was the most difficult part of my research, as I had to take all the requirements above into consideration.

Also, due to the 'paralysis' caused by the Covid - 19 pandemic in the system of world film production, live action shooting on location became prohibitive. So, I decided to make use of the possibilities software programs offered, like iClone and Blender, which I used in the storyboard planning so that the script of Kalamonas can be filmed as an animated feature film. By making such a choice, I finally came to the conclusion that do it yourself production method but also film-based research, find in the choice of animation the ideal field of application (although the completion of an animation movie requires a time-consuming process, which far exceeds the time frame of my postdoctoral research) .

In the case of an academic researcher working on such an applied field, strict adherence to the theoretical principles might have undesirable effects on the artistic aspect of the final result. For example, the produced work of art could turn out to be 
a "lifeless" realization of the theoretical model, without any artistic value. A film-based researcher wishing to work like an auteur should manage to find a balance between the validity of the scientific method and his own personal view. Such a task is extremely difficult, since the researcher will also have to function as a film producer who is interested in the artistic and commercial acceptance of his work.

To sum up, the resulting work of my postdoctoral research offers useful information on qualitative research based on the principles of film-based research, while contributing to the debate on the auteur theory in film studies. The results show that the personality of the researcher plays a catalytic role in conducting the research. The researcher can be considered as an auteur, and film-based research can be applied in terms of the cinematic production process.

\section{References}

[1] Barone , T. (2003). Challenging the Educational Imaginary: Issues of Form, Substance, and Quality in Film-Based Research. Qualitative Inquiry, 9 (2), pp. 202-217.

[2] Barone , T., \& Eisner, E. (1997). Arts Based Educational Research. Retrieved 8 20, 2018, from http://www.public.iastate.edu: http://www.public.iastate.edu/ bestler/arts_based_articles/two_arts_base d_articles/barone_eisner_arts_based_research.pdf

[3] Barone , T., \& Eisner, E. (2011). Arts Based Research. Los Angeles / London / New Delhi / Singapore / Washington DC: SAGE Publications.

[4] Bordwell, D., \& Thompson, K. (2011). Film History: an Introduction. Athens: MIET (National Bank Educational Institution).

[5] Donato , R. (2007). Raffaele Donato and Martin Scorsese - Docufictions: an interview with Martin Scorsese on documentary film- Film History: An International Journal 19: 2. Retrieved 9/10, 2018, from https://www.researchgate.net: https://www.researchgate.net/publication/254941661_Raffaele_Donato_a nd_Martin_Scorsese__Docufictions_an_interview_with_Martin_Scorsese_on_m_n_m_H_

[6] Field, S . (2005 ). Screenplay: The Foundations of Screenwriting . New York: Random House Publishing Group .

[7] Nichols, B. (1978). Fred Wiseman's Documentaries: Theory and Structure. Retrieved 8 10, 2018, from https://www.sfu.ca: http://fq.ucpress.edu/content/31/3/15

[8] Scherer, RF, \& Baker, B. (1999). Exploring Social Institutions Through the Films of Frederick Wiseman. Retrieved 8 13, 2018, from https://www.researchgate.net: https://www.researchgate.net/publication/249669633_Exploring_Social_I nstitutions_Through_the_Films_of_Frederick_Wiseman 
[9] Wood, M., \& Brown, S. (2012, 4). Film-based creative arts inquiry: Qualitative researchers as auteurs. Retrieved 925,2018 , from https://www.researchgate.net: https://www.researchgate.net/publication/275076063_Filmbased_creative_arts_enquiry_Qualitative_researchers_as_auteurs

[10] Wood, M., Salovaara , P., \& Marti, L. $(2018,1)$. Manifesto for filmmaking as organizational research. Retrieved 928,2018 , from https://www.researchgate.net: https://www.researchgate.net/publication/322424573_Manifesto_for_film making_as_organisational_research

[11] Aletras, N. D. (2018). Types of Teachers and Educational Systems in Cinema. Analysis of the most important School Movies of world film production [Doctoral Thesis]. Thessaloniki: Aristotle University of Thessaloniki, School of Fine Arts, School of Film.

[12] Dimitriou, S. (2011). The Cinema today. Athens: Savvalas.

\section{Filmography}

[13] Brown, S., \& Wood, M . (Directors). (2009). Lines of Flight [Movie]. Retrieved 9 10, 2018, from https://vimeo.com/206502465

[14] Moore, M. (Director). (2002). Bowling for Columbine [Movie].

[15] Moore, M. (Director). (2004). Fahrenheit 9/11 [Movie].

[16] Raag, I. (Director). (2007). Klass [Movie].

[17] Simon, L. (Director). (1997). Fear and Learning at Hoover Elementary [Movie].

[18] Wiseman, F. (Director). (1967). Titicut Follies [Movie].

[19] Wiseman, F. (Director). (1968). High School [Movie].

[20] Wiseman, F. (Director). (1994). High School II [Movie]. 